Jurnal Akuntansi Indonesia, Vol. 8 No. 2 Juli 2019, Hal. 167 - 183

\title{
Peranan Good University Governance Terhadap Kinerja Perguruan Tinggi
}

\author{
Zaky Machmuddah ${ }^{1}$ \\ ${ }^{1}$ Universitas Dian Nuswantoro Semarang \\ 'email:zaky_820305@yahoo.co.id
}

\begin{abstract}
Finding emperical evidence dealt with good university governance to higher education performance is the main purpose of the current research. Survey is method used in the research. Sample used in the research is higher education lecturers in Semarang. Sampling technique used is accidental sampling. Multiple linier regression with SPSS program is used to analyse data. Findings of the research are analised and described so that they can give information related to research variable. Research findings proved that transparancy, responsibility and fairness signifcantly affected to higher education performance. Therefore, for accountability and independency variables, the relation was not significant. The research findings gave empirical evidence that good university governance had effect on higher education performance. Therefore, higher education institutions should apply good university governance to improve their performance.
\end{abstract}

Keywords: good university governance mechanism, higher education performance.

\section{PENDAHULUAN}

Perguruan Tinggi adalah institusi yang sangat terkait dengan peningkatan pertumbuhan ekonomi dan partisipasi masyarakat. Sehingga kapasitas perguruan tinggi bukan hanya sebagai pencipta dan pendesiminasi ilmu pengetahuan saja, namun demikian perguruan tinggi merupakan suatu organisasi yang mampu merekut orang-orang berbakat, memunculkan ide-ide baru, memperkaya kualitas hidup dan budaya serta sebagai agen perubahan (Muktiyanto 2016).

Permasalahan perguruan tinggi di Indonesia dijadikan isu utama dalam penelitian ini. Berita yang disampaikan oleh Kementrian riset, teknologi dan pendidikan tinggi pada tahun 2017 menyatakan bahwa 25 perguruan tinggi ditutup dan sejumlah 102 perguruan tinggi dalam masa pengawasan. Dilihat dari sisi predikat akreditasi di wilayah Jawa Tengah (LLDikti 6), sebanyak 9 perguruan tinggi memperoleh predikat akreditasi A, sejumlah 65 perguruan tinggi memperoleh akreditasi B, dan sejumlah 51 perguruan tinggi memperoleh akreditasi C. Selain masalah tersebut contoh kasus lain yang menjatuhkan nama perguruan tinggi adalah penerbitan ijazah palsu. Hal ini mencerminkan bahwa tata kelola perguruan tinggi di Indonesia masih kurang baik.

Melihat fenomena tersebut, sebaiknya perguruan tinggi berbenah diri untuk memperbaiki pencitraannya. Langkah awal yang seharusnya dikerjakan adalah meningkatkan kinerja perguruan tinggi. Kinerja menurut Mulyadi (2001) adalah efektif tidaknya operasional organisasi, bagian dari organisasi serta karyawan yang 
diukur secara periodik berdasarkan standar, sasaran dan kriteria yang ditetapkan oleh organisasi sebelumnya.

Terdapat empat indikator pengukuran kinerja perguruan tinggi yang dapat digunakan pada level perguruan tinggi ataupun pada level nasional, antara lain sumber daya manusia/staf, mahasiswa, penelitian dan efisiensi keuangan (Fielden 2008). Menurut BAN PT (2010) layanan kepada mahasiswa/akademik merupakan ukuran yang menarik untuk pengukuran kinerja dari suatu perguruan tinggi. Untuk itu diperlukan suatu konsep yang dapat menjembatani antara kinerja perguruan tinggi dengan kebutuhan perguruan tinggi. Salah satu konsep yang dikenal di dunia pendidikan adalah good university governance.

Konsep good university governance (GUG) menurut Hernard dan Mitterle, (2010) merupakan elemen terpenting di perguruan tinggi karena konsep ini digunakan untuk tindakan antisipasi, perancangan, pelaksanaan, pengawasan dan penilaian terhadap efektivitas dan efisiensi dari suatu perguruan tinggi. Sehingga tujuan dari GUG adalah untuk peningkatan kualitas perguruan tinggi, peningkatan daya saing antar perguruan tinggi, peningkatan mutu internal manajemen perguruan tinggi dan tercapainya kinerja yang diharapkan (Hernard dan Mitterle, 2010 dan Salmi, 2009).

Penelitian kaitan dengan GUG beberapa kali telah dilakukan oleh para peneliti. Penelitian Wahyudin, dkk. (2017) membuktikan bahwa GUG berpengaruh signifikan terhadap struktur organisasi, manajemen perencanaan dan kinerja manajemen keuangan. Muktiyanto (2016) menunjukkan bukti bahwa adanya pengaruh langsung antara university governance terhadap kinerja. Hal ini sejalan dengan temuan penelitian dari Amilin (2016) yang menyatakan bahwa UIN Syarif Hidayatullah Jakarta telah menerapkan prinsip-prinsip GUG dan berpengaruh terhadap kinerja manajerial. Begitu pula dengan Nofianti dan Suseno (2014), Gupta dan Sharma (2014), Muhi (2010) dan Brown (2001) yang menemukan bukti sejalan yaitu university governance berpengaruh positif signifikan terhadap kinerja.

Namun demikian penelitian dari Leni dan Rasyd (2010) membuktikan bahwa corporate governance tidak berhubungan dengan kinerja perguruan tinggi. Begitu pula dengan Anggriawan dan Nurkholis (2014) membuktikan bahwa penerapan GUG di Universitas Brawijaya memiliki beberapa kendala, antara lain perubahan struktur organisasi yang sulit terwujud, tuntutan masyarakat yang semakin kompleks, sulitnya menghapus unit-unit kerja yang lama, sumber daya manusia yang kurang memadai, penerapan dua sistem akuntansi yang berbeda.

Bervariasinya temuan penelitian tersebut mendorong peneliti untuk melakukan penelitian lebih lanjut terkait dengan GUG terhadap kinerja perguruan tinggi. Berdasarkan penjelasan diatas maka tujuan penelitian ini adalah untuk menganalisis dampak good corporate governance (GCG) terhadap kinerja perguruan tinggi.

\section{KAJIAN PUSTAKA}

\section{Teori Agensi}

Jensen dan Mackling (1976) adalah pelopor dari teori agensi, yang menjelaskan bahwa adanya perbedaan kepentingan antara prinsipal (dalam hal ini pemilik perusahaan) dan agen (dalam hal ini pengelola perusahaan). Agen selaku pengelola perusahaan lebih mengetahui informasi yang ada di dalam perusahaan, sedangkan principal kurang memperoleh informasi yang ada di dalam perusahaan. Hal inilah yang menyebabkan 
terjadinya asimetri informasi antara principal dan agen, karena masing-masing memiliki kepentingan yang berbeda dan akan memenuhi kepentingannya masing-masing.

Di perguruan tinggi adanya perbedaan kepentingan antara manajemen perguruan tinggi dan yayasan menggambarkan adanya asimetri informasi, yayasan mewakili principal dan manajemen perguruan tinggi sebagai agen selaku pengelola perguruan tinggi. Hal ini akan menyebabkan munculnya agency problems. Kegagalan mengelola agency problems akan menyebabkan timbulnya agency cost.

\section{Stewardship Theory}

Puspitarini (2012) menyatakan bahwa manajemen adalah pihak yang dapat dipercaya untuk dapat bertindak sebaik-baiknya untuk kepentingan publik pada umumnya maupun shareholders pada khusunya. Sejalan dengan pendekatan agensi, stewardship theory mengemukakan bahwa tata kelola perusahaan dari suatu organisasi diperlukan untuk memastikan kepentingan pemangku kepentingan dan kelangsungan hidup jangka panjang organisasi (Davis, Schoorman \& Donaldson 1997). Perilaku manajemen tidak akan menyimpang dari kepentingan organisasi karena manajemen berusaha untuk mengoptimalkan tujuan organisasi di mana utilitas manajemen juga dimaksimalkan karena keberhasilan organisasi sangat penting untuk mencapai misi manajemen (Smallman 2004).

Stewardship theory menemukan hubungan yang kuat antara manajemen dan keberhasilan atau keberhasilan kinerja perusahaan dan oleh karena itu manajemen melindungi organisasi dan memaksimalkan kinerja (Davis, Schoorman \& Donaldson 1997), dan mencoba memuaskan sebagian besar kelompok pemangku kepentingan dalam suatu organisasi.

\section{Good University Governance (GUG)}

Shattock (2006) menjelaskan bahwa university governance merupakan suatu bentuk dan proses konstitusional pada saat suatu perguruan tinggi mengatur urusannya sendiri. Sedangkan governance itu sendiri akan melibatkan adanya suatu kebijakan dan prosedur dalam hal tindakan pengambilan keputusan dan pengendalian untuk memberikan arahan dalam pengelolaan organisasi yang efektif (Carnagie 2009). Sehingga hal ini akan menuntut suatu organisasi untuk selalu melaksanakan pengawasan, pengendalian, pengungkapan dan keterbukaan terhadap praktik-praktik yang dilakukan oleh organisasinya (Harris and Cunningham 2009).

Karakteristik perguruan tinggi berbeda dengan organisasi lainnya, sehingga ada koridor-koridor tertentu sesuai dengan nilai-nilai luhur dari sisi akademik maupun sosial. Oleh karena itu dapat disimpulkan bahwa GUG merupakan aplikasi dari prinsip-prinsip dasar dari good governance dengan berbagai penyesuaian atas dasar nilai-nilai yang harus ditegakkan dalam penyelenggaraan perguruan tinggi (Wijatno 2009).

Adapun prinsip-prinsip good governance yang harus ditegakkan adalah transparasi, akuntabilitas, responsibility, independen dan keadilan. Transparasi atau keterbukaan menjelaskan bahwa organisasi menyediakan informasi yang akurat, relevan dan dapat dimengerti oleh para pemangku kepentingan sehingga dapat digunakan sebagai dasar pengambilan keputusan. Akuntabilitas merupakan tanggung jawab 
dari organisasi kepada para stakeholders. Responsibility adalah rasa kepedulian terhadap tanggung jawab sosial atas permasalahan yang terjadi di lingkungan sekitar. Independen menunjukkan sikap yang tidak mudah dipengaruhi, sedangkan keadilan merupakan suatu upaya untuk melindungi tindakan benturan kepentingan maupun penyelewengan yang terjadi.

\section{Kinerja Perguruan Tinggi}

Kinerja merupakan suatu proses dari perilaku yang ada di dalam organisasi untuk mencapai tujuan yang telah ditetapkan dalam satu periode tertentu. Sehingga kinerja dapat diukur baik secara kuantitatif maupun secara kualitatif. Terdapat empat dimensi pengukuran kinerja dari perguruan tinggi menurut Fielden (2008), antara lain sumber daya manusia/staf, mahasiswa, penelitian, dan keuangan.

Kinerja sumber daya manusia/staf dapat dilihat dari efektivitas recruitment system, penempatan, pengembangan, retensi, pemberhentian, sistem monitoring dan evaluasi, kualifikasi akademik, kompetensi dosen, kualifikasi dan upaya peningkatan sumber daya manusia (BAN PT 2010). Kinerja mahasiswa dapat dilihat dari IPK mahasiswa (Harwati, dkk. 2015). Selain itu kinerja mahasiswa juga dapat dilihat dari jumlah kelulusan mahasiswa, lama kelulusan mahasiswa, dan jumlah lulusan diserap oleh lapangan kerja (Higgins 1989). Kinerja penelitian merupakan keseluruhan hasil penelitian yang dihasilkan oleh perguruan tinggi yang memberikan dampak pada pengembangan ilmu pengetahuan dan kesejahteraan masyarakat. Kinerja keuangan berdasarkan balance scorecard terdiri dari empat dimensi, yaitu kinerja operasi, posisi keuangan, nilai universitas dan tertib keuangan (Djokopranoto, 2006).

\section{Pengembangan Hipotesis}

Good University Governance (GUG) diukur dengan menggunakan instrument yang terdapat pada prinsip-prinsip good governance. Adapun prinsip-prinsip good governance tersebut antara lain: transparasi, akuntabilitas, responsibility, independen dan keadilan. Instrumen ini digunakan untuk menangkap sejauh mana kualitas penerapan GUG di suatu perguruan tinggi. Penerapan GUG yang baik akan berpengaruh pada kinerja perguruan tinggi, hal ini berarti bahwa semakin baik penerapan GUG di perguruan tinggi maka akan meningkatkan kinerja perguruan tinggi, begitu pula sebaliknya semakin buruk penerapan GUG di perguruan tinggi maka akan semakin menurunkan kinerja perguruan tinggi.

Implementasi GUG timbul sebagai bentuk usaha untuk meminimalisir perbedaan kepentingan antara prinsipal dan agen yang dipopulerkan oleh Jensen and Mackling (1976). Sejalan dengan pendekatan agensi, stewardship theory mengemukakan bahwa tata kelola perusahaan dari suatu organisasi diperlukan untuk memastikan kepentingan pemangku kepentingan dan kelangsungan hidup jangka panjang organisasi (Davis, Schoorman \& Donaldson, 1997). Perilaku manajemen tidak akan menyimpang dari kepentingan organisasi karena manajemen berusaha untuk mengoptimalkan tujuan organisasi dimana utilitas manajemen juga dimaksimalkan karena keberhasilan organisasi sangat penting untuk mencapai misi manajemen (Smallman 2004).

Penelitian Wahyudin, dkk. (2017), Muktiyanto (2016), Amilin (2016), Muhi (2010) dan Brown (2001) telah 
membuktikan bahwa GUG berpengaruh terhadap kinerja perguruan tinggi. Argumentasi ini dijadikan sebagai dasar membuat bangunan hipotesis, oleh karena itu hipotesi dalam penelitian ini adalah sebagai berikut:

$\mathrm{H}_{1}$ : transparacy berpengaruh signifikan terhadap kinerja perguruan tinggi.

$\mathrm{H}_{2}$ : accountability berpengaruh signifikan terhadap kinerja perguruan tinggi.

$\mathrm{H}_{3}$ : responsibility berpengaruh signifikan terhadap kinerja perguruan tinggi.

$\mathrm{H}_{4}$ : independency berpengaruh signifikan terhadap kinerja perguruan tinggi.

$\mathrm{H}_{5}$ : fairness berpengaruh signifikan terhadap kinerja perguruan tinggi.

\section{METODE PENELITIAN}

Seluruh dosen perguruan tinggi di kota Semarang dijadikan populasi dalam penelitian ini. Sampel yang digunakan dalam penelitian ini adalah sebagian dosen perguruan tinggi yang berada di kota Semarang, karena teknik pengambilan sampel dilakukan dengan accidental sampling. Metode penelitian ini dengan melakukan survey. Data diperoleh dengan menyebarkan kuesioner kepada responden yang dipilih. Adapun responden dalam penelitian ini adalah dosen yang memiliki jabatan struktural di perguruan tingginya, dengan posisi jabatan sebagai rektor, wakil rektor, dekan, wakil dekan, ketua program studi, wakil ketua program studi, kepala biro, kepala bagian, ataupun kepala sub bagian.

Variabel penelitian adalah peneliti memilih objek untuk dikaji dan selanjutnya ditarik kesimpulannya (Sugiyono 2011). Bagian tersebut berisi deskripsi variabel-variabel yang diteliti, harus bisa didefinisikan lebih operasional. Sesudah didefinisikan variabel penelitian harus bisa diukur sesuai kaidah, dan secara akademis umum diterima. Penelitian ini menggunakan dua variabel yaitu: variabel independen dan variabel dependen.

Pengukuran variabel tersebut menggunakan skala likert dimana setiap pernyataan diberi skor atau poin dari 1-5. Berikut ini adalah contoh pemberian skor penelitian: sangat sulit (1), sulit (2), netral (3), mudah (4), dan sangat mudah (5); tidak dilakukan (1), jarang dilakukan (2), netral (3), dilakukan tanpa jadwal tetap (4) dan secara berkala dilakukan (5); tidak pernah (1), jarang dilakukan (2), netral (3), sering dilakukan (4) dan terjadwal (5); sangat tidak independen (1), tidak independen (2), netral (3), independen (4) dan sangat independen (5).

Variabel dependen adalah variabel yang dipengaruhi karena variabel independen ada (Sugiyono 2011). Variabel dependen $(\mathrm{Y})$ ialah kinerja perguruan tinggi. Pengukuran variabel dependen menggunakan indikator yaitu sistem pengendalian internal dan satuan pengendalian internal, sistem jaminan mutu, akreditasi BAN PT dan sertifikasi sistem jaminan mutu (misalnya ISO), sistem informasi akuntansi dan manajemen serta penerapan information communication and technology (ICT), layanan akademik institusi, rerata indeks prestasi kumulatif mahasiswa, rerata lama kelulusan mahasiswa, persentase lulusan diserap oleh lapangan kerja atau melanjutkan studi setelah 6 bulan, pedoman dan atau panduan perekrutan dan pengembangan dosen/ pegawai, pedoman evaluasi kinerja dosen/pegawai yang telah dilaksanakan, serta ketepatan waktu dosen menyerahkan nilai evaluasi hasil belajar.

Variabel independen ialah variabel yang mempengaruhi perubahan timbulnya variabel dependen. Variabel independen (X) terdiri dari transparacy, accountability, responsibility, independency dan fairness. Definisi operasional adalah penjelasan definisi dari variabel yang telah dipilih oleh peneliti. Pendefinisian variabel 
penelitian harus berdasarkan pada apa yang telah dideskripsikan dalam tinjauan pustaka. Definisi operasional variabel boleh dilandaskan pada satu atau lebih rujukan, juga dibarengi argumen yang melandasi pemakaian definisi yang dimaksud. Berikut ini dijelaskan definisi operasional variabel-variabel penelitian:

\section{Transparacy (X1)}

Transparasi atau keterbukaan menjelaskan bahwa organisasi menyediakan informasi yang akurat, relevan dan dapat dimengerti oleh para pemangku kepentingan sehingga dapat digunakan sebagai dasar pengambilan keputusan. Transparacy diukur dengan menggunakan indikator (Muktiyanto, 2016):

1. Aksesabilitas laporan keuangan dan laporan akademik institusi,

2. Aksesabilitas informasi tentang institusi melalui information communication and technology (ICT),

3. Aksesabilitas notulen rapat institusi,

\section{Accountability (X2)}

Akuntabilitas merupakan tanggung jawab dari organisasi kepada para stakeholders. Pernyataan untuk mengukur accountability menggunakan indikator pernyataan sebagai berikut (Muktiyanto, 2016):

1. Evaluasi pencapaian tujuan, prestasi mahasiswa, penyerapan lulusan program studi,

2. Tindakan pencegahan dan penanganan risiko,

3. Mekanisme penyebaran informasi tujuan institusi, prestasi mahasiswa, dan penyerapan lulusan,

4. Rapat manajemen institusi sebagai tindak lanjut atas temuan audit mutu eksternal maupun internal,

5. Mekanisme evaluasi atas penyelenggaraan institusi.

\section{Responsibility (X3)}

Responsibility adalah rasa kepedulian terhadap tanggung jawab sosial atas permasalahan yang terjadi di lingkungan sekitar. Responsibility diukur menggunakan indikator sebagai berikut (Muktiyanto, 2016):

1. Berkenaan reanalisis kurikulum institusi, dalam 5 tahun terakhir,

2. Adanya studi kelayakan kebutuhan berbasis kurikulum dan pasar, dalam 5 tahun terakhir,

3. Kegiatan bersama institusi, asosiasi dan atau masyarakat, dalam 5 tahun terakhir,

4. Kegiatan CSR institusi, dalam 5 tahun terakhir.

\section{Independency (X4)}

Independen menunjukkan sikap yang tidak mudah dipengaruhi. Independency diukur dengan menggunakan indikator, sebagai berikut (Muktiyanto, 2016):

1. Penentuan kebijakan penerimaan mahasiswa,

2. Penentuan mekanisme jaminan mutu,

3. Pembukaan program studi/jurusan baru,

4. Memperoleh dan menggali dana,

5. Kontrak kerjasama,

6. Perekrutan dosen dan staf. 


\section{Fairness (X5)}

Keadilan merupakan suatu upaya untuk melindungi tindakan benturan kepentingan maupun penyelewengan yang terjadi. Fairness diukur dengan menggunakan indikator, sebagai berikut (Muktiyanto, 2016):

1. Berkenaan dengan key performance indicator dalam menilai kinerja,

2. Berkenaan dengan beasiswa pendidikan untuk mahasiswa kurang mampu,

3. Berkenaan dengan sistem remunerasi,

4. Berkenaan dengan perwakilan institusi pada senat universitas,

\section{Kinerja Perguruan Tinggi (Y)}

Kinerja merupakan suatu proses dari perilaku yang ada di dalam organisasi untuk mencapai tujuan yang telah ditetapkan dalam satu periode tertentu. Pernyataan untuk mengukur kinerja perguruan tinggi menggunakan indikator pernyataan sebagai berikut (Muktiyanto, 2016):

1. Berkenaan dengan sistem pengendalian internal dan satuan pengendalian internal,

2. Berkenaan dengan sistem jaminan mutu,

3. Berkenaan dengan akreditasi BAN PT dan sertifikasi sistem jaminan mutu (misalnya ISO),

4. Berkenaan dengan sistem informasi akuntansi dan manajemen serta penerapan information communication and technology (ICT),

5. Layanan akademik institusi melalui program studi,

6. Rerata indeks prestasi kumulatif mahasiswa (IPK),

7. Rerata lama kelulusan mahasiswa,

8. Persentase lulusan diserap oleh lapangan kerja atau melanjutkan studi setelah 6 bulan,

9. Adanya pedoman dan atau panduan perekrutan dan pengembangan dosen/pegawai,

10. Adanya pedoman evaluasi kinerja dosen/pegawai yang telah dilaksanakan,

11. Ketepatan waktu dosen menyerahkan nilai evaluasi hasil belajar.

Penelitian ini menggunakan uji validitas dan reliabilitas untuk menunjukkan bahwa analisis faktor adalah tepat dan variabel yang digunakan adalah reliabel. Untuk analisis data penelitian ini menggunakan uji normalitas, yang menunjukkan bahwa data yang diuji normal. Selain itu penelitian ini juga menggunakan uji regresi berganda, yang mempunyai rumus persamaan sebagai berikut:

$\mathrm{Y}=\mathrm{a} 1+\mathrm{b} 1 \mathrm{X} 1+\mathrm{b} 2 \mathrm{X} 2+\mathrm{b} 3 \mathrm{X} 3+\mathrm{b} 4 \mathrm{X} 4+\mathrm{b} 5 \mathrm{X} 5+\mathrm{e}$

Keterangan:

a : konstanta

b : koefisien regresi variabel bebas

$\mathrm{X} 1$ : variabel transparacy

$\mathrm{X} 2$ : variabel accountability

$\mathrm{X} 3$ : variabel responsibility

$\mathrm{X} 4$ : variabel independency

Peranan Good University Governance Terhadap Kinerja Perguruan Tinggi 
X5: variabel fairness

$Y$ : variabel kinerja keuangan

e : error

Uji kelayakan model yang digunakan dalam penelitian ini ada dua yaitu uji statistik F dan uji t. Uji statistik F digunakan untuk mengetahui apakah model layak untuk dianalisis lebih lanjut dan uji t berguna untuk menguji pengaruh suatu variabel independen ke variabel dependen secara individual. Selain itu, uji koefisien determinasi juga digunakan dengan tujuan untuk mengukur seberapa jauh kemampuan model dalam menjelaskan variasi variabel dependen.

\section{HASIL DAN PEMBAHASAN}

Dosen-dosen perguruan tinggi di kota Semarang dijadikan Responden dalam penelitian ini. Penentuan jumlah sampel penelitian ini menggunakan rumus Slovin, dengan batas toleransi error sebanyak 5\% maka diperoleh sampel sebanyak 100 dosen. Dari sejumlah 100 responden tersebut 21 responden tidak mengembalikan dan mengembalikan tetapi tidak mengisi kuesioner serta 11 responden tidak mengisi kuesioner secara lengkap. Sehingga sampel yang diperoleh dalam penelitian ini sebanyak 68 responden.

Dari 68 responden tersebut 54.4\% responden berjenis kelamin laki-laki, 38.2\% berjenis kelamin perempuan dan sisanya tidak memberikan informasi terkait dengan jenis kelamin responden. Berdasarkan data usia responden 33.8\% responden berusian 30-40 tahun, 35.3\% responden berusia 41-50 tahun, 20.6\% responden berusia 51 tahun keatas, sedangkan 10.3\% responden tidak memberikan informasi terkait dengan usia responden. 51.5\% responden berpendidikan S2 dan sisanya berpendidikan S3. Rata-rata masa kerja responden bekerja selama 16 tahun.

\section{Analisis Data}

Uji reliabilitas digunakan untuk mengukur suatu kuesioner yang merupakan indikator dari variabel atau konstruk. Suatu kuesioner dikatakan reliabel atau handal jika jawaban seseorang terhadap pertanyaan dijawab responden secara konsisten atau stabil dari waktu ke waktu. Suatu konstruk atau variabel dikatakan reliabel jika memberikan nilai Cronbach Alpha lebih besar dari 0,70 (lihat tabel 1).

Berdasarkan data tabel 1 menunjukkan bahwa untuk indikator-indikator dari seluruh variabel yang ada dalam poin pertanyaan menunjukkan bahwa koefisien Cronbach's Alpha nilainya lebih dari 0,70. Hal ini dapat disimpulkan bahwa keseluruhan variabel tersebut adalah reliabel.

Uji validitas dilakukan dengan cara membandingkan nilai $r$ hitung (correlation item total correlation) dengan nilai $r$ tabel dengan ketentuan untuk degree of freedom (df) $=n-2$, dimana $n$ adalah jumlah sampel.

Jika $r_{\text {hitung }}>r_{\text {tabel' }}$ berarti pernyataan tersebut dinyatakan valid. Namun apabila $r_{\text {hitung }}<r_{\text {tabel' }}$ berarti pernyataan tersebut dinyatakan tidak valid. Diketahui DF adalah $(N-2)$ yaitu $(68-2)=66$ dan a $=0,05$, maka nilai dari $r_{\text {tabel }}$ adalah 0,2012.

Berdasarkan tabel di atas dapat dilihat uji validitas dari variabel $\mathrm{X}_{1}, \mathrm{X}_{2^{\prime}}, \mathrm{X}_{3^{\prime}}, \mathrm{X}_{4^{\prime}}, \mathrm{X}_{5^{\prime}}$ dan $\mathrm{Y}$ menunjukkan bahwa 
pada korelasi masing-masing indikator terhadap total skor konstruk (pertanyaan) menunjukkan hasil yang

signifikan dan $r_{\text {hitung }}$ lebih besar dari $r_{\text {tabel }}\left(r_{\text {hitung }}>r_{\text {tabel }}\right)$. Jadi hal ini dapat disimpulkan bahwa masing-masing indikator pertanyaan adalah valid.

Analisis regresi linier berganda (multiple regression) digunakan untuk menguji pengaruh lebih dari satu variabel bebas (metrik) terhadap satu variabel terikat metrik (Ghozali 2011:17). Uji regresi linier berganda juga dapat menunjukkan arah hubungan antara variabel bebas (independent) dengan variabel terikat (dependent). Dalam penelitian ini menggunakan regresi linier berganda karena memiliki satu variabel dependent dan lebih dari satu variabel independen. Berikut ini adalah hasil dari pengujian regresi linier berganda:

Berdasarkan data yang tersaji dalam tabel 5 menunjukkan bahwa secara bersama-sama GUG berpengaruh signifikan terhadap kinerja perguruan tinggi. Artinya bahwa prinsip-prinsip yang ada dalam GUG antara lain transparancy, accountability, responsibility, independency dan fairness mempengaruhi kinerja dari perguruan tinggi. Hasil temuan penelitian ini sesuai dengan Wahyudin, dkk. (2017), Muktiyanto (2016), Amilin (2016), Muhi (2010) dan Brown (2001).

\section{Hasil Penelitian Pengaruh Transparancy terhadap Kinerja Perguruan Tinggi}

Hasil uji analisis regresi linier berganda yang tersaji dalam tabel 6 menunjukkan bahwa tingkat signifikansi transparancy terhadap kinerja perguruan tinggi sebesar 0,017 hal ini berarti transparancy berpengaruh terhadap kinerja perguruan tinggi. Keterbukaan yang dilakukan oleh perguruan tinggi melalui program studi yang direpresentasikan dengan kemudahan mengakses informasi yang akurat, relevan dan mudah dimengerti yang diperoleh secara low cost sehingga stakeholders dapat mengambil keputusan yang tepat, maka akan mendorong peningkatan kinerja perguruan tinggi.

Hal ini sesuai dengan pendekatan agensi dan stewardship theory yang menjelaskan bahwa tata kelola perusahaan dari suatu organisasi diperlukan untuk memastikan kepentingan pemangku kepentingan dan kelangsungan hidup jangka panjang organisasi (Davis, Schoorman \& Donaldson, 1997). Perilaku manajemen tidak akan menyimpang dari kepentingan organisasi karena manajemen berusaha untuk mengoptimalkan tujuan organisasi di mana utilitas manajemen juga dimaksimalkan karena keberhasilan organisasi sangat penting untuk mencapai misi manajemen (Smallman 2004).

Temuan penelitian ini sejalan dengan temuan penelitian yang dilakukan oleh Wahyudin, dkk. (2017), Muktiyanto (2016), Amilin (2016), Nofianti dan Suseno (2014), Gupta dan Sharma (2014), Muhi (2010) dan Brown (2001). Namun demikian, temuan penelitian ini tidak sejalan dengan penelitian Leni dan Rasyd (2010) serta Anggriawan dan Nurkholis (2014).

\section{Hasil Penelitian Pengaruh Accountability terhadap Kinerja Perguruan Tinggi}

Data hasil pengujian yang tersaji di dalam tabel 6 menunjukkan bahwa nilai signifikansi untuk accountability terhadap kinerja perguruan tinggi sebesar 0,203. Artinya hipotesis kedua dalam penelitian ini ditolak yang berarti bahwa accountability tidak berpengaruh terhadap kinerja perguruan tinggi.

Institusi perguruan tinggi harus mampu mempertanggungjawabkan seluruh rangkaian proses 
penyelenggaraan perguruan tinggi terhadap seluruh stakeholders, baik internal maupun eksternal, terutama pada masyarakat umum. Pertanggungjawaban ini dapat dilakukan secara rutin dan dalam jangka waktu tertentu. Hasil audit maupun laporan yang lainnya harus dengan mudah dapat diakses oleh seluruh stakeholders, hal ini yang sering tidak dilakukan oleh perguruan tinggi. Sebenarnya akuntabilitas itu sendiri merupakan kewajiban mempertanggungjawabkan keberhasilan atau kegagalan pelaksanaan misi organisasi dalam mencapai tujuan dan sasaran yang telah ditetapkan sebelumnya, melalui media pertanggungjawaban secara periodik (Gala 2013).

Argumentasi tersebut sejalan dengan hasil temuan penelitian Jitmau, dkk (2017) yang membuktikan bahwa akuntabilitas tidak berpengaruh terhadap kinerja pemerintah daerah karena pemerintah gagal dalam menjalankan misi untuk mencapai tujuan dan sasaran yang telah ditetapkan sebelumnya secara periodik, terbukti bahwa perencanaan awal tidak sama dengan pencapaian hasil akhir. Begitu juga dengan hasil penelitian dari Astuti (2013) membuktikan bahwa akuntabilitas tidak berpengaruh terhadap kinerja pemerintah daerah di DPPKAD Kabupaten Grobogan.

\section{Hasil Penelitian Pengaruh Responsibility terhadap Kinerja Perguruan Tinggi}

Tabel 6 menunjukkan bahwa tingkat signifikansi responsibility terhadap kinerja perguruan tinggi sebesar 0,011 berarti bahwa responsibility berpengaruh terhadap kinerja perguruan tinggi. Responsiveness merupakan kesigapan dan akurasi dari perguruan tinggi dalam merespon permintaan dari stakeholders untuk ditindaklanjuti. Permasalahan-permasalahan yang terjadi akan ditanggapi sesuai dengan harapan stakeholders. Ini merupakan wujud tanggungjawab sosial dan penjaminan suasana dan lingkungan akademik yang kondusif. Sehingga kondisi ini akan mempengaruhi kinerja dari perguruan tinggi.

Hal ini sesuai dengan pendekatan agensi dan stewardship theory yang menjelaskan bahwa tata kelola perusahaan dari suatu organisasi diperlukan untuk memastikan kepentingan pemangku kepentingan dan kelangsungan hidup jangka panjang organisasi (Davis, Schoorman \& Donaldson, 1997). Perilaku manajemen tidak akan menyimpang dari kepentingan organisasi karena manajemen berusaha untuk mengoptimalkan tujuan organisasi di mana utilitas manajemen juga dimaksimalkan karena keberhasilan organisasi sangat penting untuk mencapai misi manajemen (Smallman 2004).

Temuan penelitian ini sejalan dengan temuan penelitian yang dilakukan oleh Wahyudin, dkk. (2017), Muktiyanto (2016), Amilin (2016), Nofianti dan Suseno (2014), Gupta dan Sharma (2014), Muhi (2010) dan Brown (2001). Namun demikian, temuan penelitian ini tidak sejalan dengan penelitian Leni dan Rasyd (2010) serta Anggriawan dan Nurkholis (2014).

\section{Hasil Penelitian Pengaruh Independency terhadap Kinerja Perguruan Tinggi}

Berdasarkan tabel 6 menunjukkan bahwa tingkat signifikansi untuk pengaruh independency terhadap kinerja perguruan tinggi sebesar 0,562. Artinya independency tidak berpengaruh terhadap kinerja perguruan tinggi. Independensi merupakan sikap yang tidak terpengaruh.

Temuan penelitian ini sejalan dengan penelitian Widhi dan Setyawati (2015) serta Rahayu (2008) yang 
membuktikan bahwa auditor yang memiliki independensi yang rendah maka dia akan mudah terpengaruh dan dikendalikan oleh pihak lain dalam mempertimbangkan fakta yang dijumpai saat pemeriksaan dan dalam merumuskan serta menyatakan pendapatnya. Hal tersebut sejalan dengan temuan penelitian dari Salju, dkk. (2014) yang membuktikan bahwa independensi aparat inspektorat kabupaten Luwu Timur tidak berpengaruh terhadap kinerja auditor, artinya independensi aparat inspektorat kabupaten Luwu Timur masih terpengaruh dengan penentu kebijakan. Artinya pada saat penyusunan program pemeriksaan masih ada intervensi pimpinan untuk menentukan, mengeliminasi atau memodifikasi bagian-bagian tertentu yang akan diperiksa serta intervensi atas prosedur-prosedur yang dipilh auditor. Meskipun aparat sering kali mendapat fasilitas dari instansi yang diaudit, namun aparat tetap menganggap bahwa audit yang baik tetap harus dilaksanakan.

\section{Hasil Penelitian Pengaruh Fairness terhadap Kinerja Perguruan Tinggi}

Tingkat signifikansi fairness terhadap kinerja perguruan tinggi berdasarkan pada tabel 6 sebesar 0,000 hal ini berarti fairness berpengaruh terhadap kinerja perguruan tinggi. Fairness merupakan pelaksanaan kegiatan berazaskan kewajaran dan kesetaraan untuk kepentingan pemegang saham dan para pemangku kepentingan lainnya. Artinya stakeholders akan terlindungi dari upaya penyelewengan baik dalam bentuk usaha untuk kepentingan pribadi maupun benturan kepentingan atau praktik perguruan tinggi yang tidak sehat (Anggriawan dan Nurkholis 2014). Terkait dengan mahasiswa, praktik fairness dapat dilihat dari adanya skema subsidi dan alokasi biaya pendidikan untuk mahasiswa yang kurang mampu (Muktiyanto 2016). Sehingga semakin perguruan tinggi tersebut fairness maka kinerja perguruan tinggi akan ikut berpengaruh.

$\mathrm{Hal}$ ini sesuai dengan pendekatan agensi dan stewardship theory yang menjelaskan bahwa tata kelola perusahaan dari suatu organisasi diperlukan untuk memastikan kepentingan pemangku kepentingan dan kelangsungan hidup jangka panjang organisasi (Davis, Schoorman \& Donaldson, 1997). Perilaku manajemen tidak akan menyimpang dari kepentingan organisasi karena manajemen berusaha untuk mengoptimalkan tujuan organisasi di mana utilitas manajemen juga dimaksimalkan karena keberhasilan organisasi sangat penting untuk mencapai misi manajemen (Smallman 2004).

Temuan penelitian ini sejalan dengan temuan penelitian yang dilakukan oleh Wahyudin, dkk. (2017), Muktiyanto (2016), Amilin (2016), Nofianti dan Suseno (2014), Gupta dan Sharma (2014), Muhi (2010) dan Brown (2001). Namun demikian, temuan penelitian ini tidak sejalan dengan penelitian Leni dan Rasyd (2010) serta Anggriawan dan Nurkholis (2014).

\section{KESIMPULAN, KETERBATASAN DAN SARAN}

Hasil penelitian membuktikan bahwa variabel transparacy, responsibility dan fairness berpengaruh signifikan terhadap kinerja perguruan tinggi. Namun demikian untuk variabel accountability dan independency tidak berpengaruh terhadap kinerja perguruan tinggi. Secara bersama-sama variabel-variabel tersebut berpengaruh signifikan terhadap kinerja perguruan tinggi. Implikasi dari penelitian ini adalah membuktikan bahwa good university governance berperan terhadap kinerja perguruan tinggi, sehingga perguruan tinggi diharuskan menerapkan good university governance untuk meningkatkan kinerja perguruan tingginya. 
Keterbatasan dari penelitian ini adalah sedikitnya pengembalian data dari responden karena responden yang ditemuai memiliki kesibukan di jabatan struktural, sehingga data dalam penelitian ini sangat minim. Saran dari penelitian ini adalah untuk memperbanyak jumlah data penelitian agar hasilnya dapat mengeneralisasi perguruan tinggi di Indonesia. 


\section{DAFTAR PUSTAKA}

Agriawan, F.F. dan Nurkholis. 2014. "Good Corporate Governance in The Public Service Agency (Cace Study at University of Brawijaya Malang)." Jurnal Ilmiah Mahasiswa FEB, Vol. 2, No. 2.

Amilin. 2016. “Dampak Penerapan Good University Governance Terhadap Kinerja Manajerial Melalui Implementasi Anggaran Berbasis Partisipatif." Jurnal Akuntansi, Vol. XX, No. 03: 330-344.

BAN PT. 2010. “Akreditasi Program Studi Sarjana (S1) PTTJJ." Buku VIA: Matriks Penilaian Borang dan Evaluasi Diri Program Studi. Jakarta.

Brownir, William O. 2001. " Faculty Participation in University Governance and The Effects on University Performance." Journal of Economic Behavior \& Organization, Vol. 44, Issue 2: 129-143.

Carnagie, G.D. 2009. “The ABC of University Governance.” Campus review, 19 (9), 8.

Fielden, J. 2008. "Global Trends in University Governance." Education Working Paper Series N 9, Washington, D.C.: World Bank.

Ghozali, I. 2011. "Aplikasi Analisis Multivariate dengan Program SPSS." Badan Penerbit Undip.

Gupta, P. and A. M. Sharma. 2014. "A Study of the Impact of Corporate Governance Practices on Firm Performance in Indiaan and South Korean Companies." Procedia-Social and Behavioral Sciences, Vol. 133: 4-11.

Harris, J. and G. Cunningham. 2009. "The Time are Changing: a Call for Governing Boards of Universities to Awaken to Sarbanes-Oxley and Practices of Good Governance. Dicision line, 40 (5), 21.

Harwati, A., A. Pemata, W.F. Ayu. 2015. "Mapping Student's Performance Based on Data Mining Approach (A Case Study)." Agriculture and Agricultural Science Procedia, Vol. 3: 173-177.

Henard, Febrice., Mitterle, Alexander. 2010. “Governance and Quality Guidelines in Higher Education. OECD.

Higgins, J.C. 1989. "Performance Measurement in Universities." European Journal of Operational Research, Vol. 38, Issue 3: 358-368.

Jensen, C.M. and W.H. Meckling. 1976. "Theory of The Firm: Managerial Behavior, Agency Cost and Ownership Structure." Journal of Financial Economic 3: 305-360.

Leni dan R. Rasyd. 2010. " Implikasi Penerapan Corporate Governance Terhadap Kinerja Perusahaan Pada Perusahaan Bank." Jurnal Akuntansi, Vol. XIV.

Muhi, A.H. 2010. "Implementasi Nilai-nilai Good Governance di Perguruan Tinggi." Dr disertasi, Sekolah Pascasarjana UPI.

Muktiyanto, A. 2016. "Good University Governance dan Kinerja Program Studi: Pengaruh Penerapan Akuntansi Manajemen, Teknik Manajemen, dan Pilihan Prioritas Strategi Sebagai Model Mediasi Fit." Dr disertasi, Universitas Indonesia,.

Mulyadi. 2001. Akuntansi Manajemen: Konsep, Manfaat dan Rekayasa. Edisi ketiga: Salemba empat, Jakarta, Nofianti, L. dan N. S. Suseno. 2014. “Factors Affectting Implementation of Good Government Governance (GGG) and Their Implications to Wards Performance Accountability." Procedia-Social and Behavioral Sciences, Vol.164: 98-105. 
Puspitarini, N.D. 2012. “Peran Satuan Pengawasan Intern Dalam Pencapaian Good University Governance Pada Perguruan Tinggi Berstatus PK-BLN." Accounting Analys Journal, Vol. I (2).

Salju, Rismawati, M.D. Bachtiar. 2014. "Pengaruh Kompetensi dan Independensi terhadap Kinerja Auditor Pemerintah Kabupaten Lawu Timur." Jurnal Equilibrium, Vol. 04, No. 02:100-123.

Salmi. J. 2009. "The Growing Accountability Agenda in Tertiary Education: Progress or Mixed Blessing?". Education Working Paper Series N 16, Washington, D.C.: World Bank.

Snattock, M. 2006. "Managing and Good Governance in Higher Education." Maidenhead, Berkshire. Open University Press.

Sugiyono. 2011. "Metode Penelitian Kuantitatif, Kualitatif dan R \& D." Alfabeta, Bandung.

Wahyudin, A., Nurkhin, A., Kiswanto. 2017. “Hubungan Good University Governance Terhadap Kinerja Manajemen Keuangan Perguruan Tinggi." Jurnal Keuangan dan Perbankan, 21 (1): 60-69.

Wijatno, S. 2009. "Pengelolaan Perguruan Tinggi Secara Efisien, Efektif dan Ekonomis Untuk Meningkatkan Penyelenggaraan Pendidikan dan Mutu Lulusan." Salemba Empat.

www.kopertis6.or.id. 


\section{LAMPIRAN}

Tabel 1. Hasil Uji Reliabilitas

\begin{tabular}{lccc}
\hline \multicolumn{1}{c}{ Vaiabel } & Ketentuan & Cronbach Alpha & Keterangan \\
\hline Transparancy $\left(\mathrm{X}_{1}\right)$ & $>0,70$ & 0,827 & Reliabel \\
\hline Accountability $\left(\mathrm{X}_{2}\right)$ & $>0,70$ & 0,874 & Reliabel \\
\hline Responsibility $\left(\mathrm{X}_{3}\right)$ & $>0,70$ & 0,859 & Reliabel \\
\hline Independency $\left(\mathrm{X}_{4}\right)$ & $>0,70$ & 0,867 & Reliabel \\
\hline Fairness $\left(\mathrm{X}_{5}\right)$ & $>0,70$ & 0,837 & Reliabel \\
\hline Performance $(\mathrm{Y})$ & $>0,70$ & 0,870 & Reliabel \\
\hline
\end{tabular}

Sumber : Data primer yang diolah (2019)

Tabel 2. GCG Reliability Statistics

\begin{tabular}{rrr}
\hline $\begin{array}{c}\text { Cronbach's } \\
\text { Alpha }\end{array}$ & $\begin{array}{c}\text { Cronbach's Alpha Based } \\
\text { on Standardized Items }\end{array}$ & N of Items \\
\hline, 864 &, 873 & 6 \\
\hline
\end{tabular}

Sumber : Data primer yang diolah (2019)

Tabel 3. Hasil Uji Validitas

\begin{tabular}{lccc}
\hline \multicolumn{1}{c}{ Variabel } & $\mathbf{t}_{\text {hitung }}$ & $\mathbf{r}_{\text {tabel }}$ & Keterangan \\
\hline Transparancy $\left(\mathrm{X}_{1}\right)$ & & & \\
\hline $\mathrm{X}_{1.1}$ & 0,531 & 0,2012 & Valid \\
\hline $\mathrm{X}_{1.2}$ & 0,712 & 0,2012 & Valid \\
\hline $\mathrm{X}_{1.3}$ & 0,482 & 0,2012 & Valid \\
\hline Accountability $\left(\mathrm{X}_{2}\right)$ & & & \\
\hline $\mathrm{X}_{2.1}$ & 0,739 & 0,2012 & Valid \\
\hline $\mathrm{X}_{2.2}$ & 0,589 & 0,2012 & Valid \\
\hline $\mathrm{X}_{2.3}$ & 0,581 & 0,2012 & Valid \\
\hline $\mathrm{X}_{2.4}$ & 0,649 & 0,2012 & Valid \\
\hline $\mathrm{X}_{2.5}$ & 0,636 & 0,2012 & Valid \\
\hline Responsibility $\left(\mathrm{X}_{3}\right)$ & & & \\
\hline $\mathrm{X}_{3.1}$ & 0,573 & 0,2012 & Valid \\
\hline $\mathrm{X}_{3.2}$ & 0,677 & 0,2012 & Valid \\
\hline $\mathrm{X}_{3.3}$ & 0,707 & 0,2012 & Valid \\
\hline $\mathrm{X}_{3.4}$ & 0,523 & 0,2012 & Valid \\
\hline Independency $\left(\mathrm{X}_{4}\right)$ & & & \\
\hline $\mathrm{X}_{4.1}$ & 0,687 & 0,2012 & Valid \\
\hline $\mathrm{X}_{4.2}$ & 0,605 & 0,2012 & Valid \\
\hline $\mathrm{X}_{4.3}$ & 0,560 & 0,2012 & Valid \\
\hline $\mathrm{X}_{4.4}$ & 0,501 & 0,2012 & Valid \\
\hline $\mathrm{X}_{4.5}$ & 0,678 & 0,2012 & Valid \\
\hline & & & \\
\hline
\end{tabular}

Peranan Good University Governance Terhadap Kinerja Perguruan Tinggi 


\begin{tabular}{|c|c|c|c|}
\hline Variabel & $\mathbf{t}_{\text {hitung }}$ & $\mathbf{r}_{\text {tabel }}$ & Keterangan \\
\hline $\mathrm{X}_{4.6}$ & 0,604 & 0,2012 & Valid \\
\hline \multicolumn{4}{|l|}{ Fairness $\left(\mathrm{X}_{5}\right)$} \\
\hline $\mathrm{X}_{5.1}$ & 0,702 & 0,2012 & Valid \\
\hline $\mathrm{X}_{5.2}$ & 0,451 & 0,2012 & Valid \\
\hline $\mathrm{X}_{5.3}$ & 0,631 & 0,2012 & Valid \\
\hline $\mathrm{X}_{5.4}$ & 0,565 & 0,2012 & Valid \\
\hline \multicolumn{4}{|l|}{ Performance $(\mathrm{Y})$} \\
\hline $\mathrm{Y}_{1}$ & 0,685 & 0,2012 & Valid \\
\hline $\mathrm{Y}_{2}$ & 0,496 & 0,2012 & Valid \\
\hline $\mathrm{Y}_{3}$ & 0,727 & 0,2012 & Valid \\
\hline $\mathrm{Y}_{4}$ & 0,386 & 0,2012 & Valid \\
\hline $\mathrm{Y}_{5}$ & 0,572 & 0,2012 & Valid \\
\hline $\mathrm{Y}_{6}$ & 0,509 & 0,2012 & Valid \\
\hline $\mathrm{Y}_{7}$ & 0,315 & 0,2012 & Valid \\
\hline $\mathrm{Y}_{8}$ & 0,577 & 0,2012 & Valid \\
\hline $\mathrm{Y}_{9}$ & 0,612 & 0,2012 & Valid \\
\hline$Y_{10}$ & 0,649 & 0,2012 & Valid \\
\hline $\mathrm{Y}_{11}$ & 0,480 & 0,2012 & Valid \\
\hline
\end{tabular}

Sumber: Data primer yang diolah (2019)

Tabel 4. Model Summary

\begin{tabular}{lcccc}
\hline Model & $\mathbf{R}$ & R Square & $\begin{array}{c}\text { Adjusted R } \\
\text { Square }\end{array}$ & $\begin{array}{c}\text { Std. Error of the } \\
\text { Estimate }\end{array}$ \\
\hline 1 &, $829^{\mathrm{a}}$ &, 687 &, 662 &, 37028 \\
\hline a. Predictors: (Constant), Fairness, & Transparancy, Accountability, \\
Responsibility, Independency & &
\end{tabular}

Tabel 5. ANOVA

\begin{tabular}{rl|r|r|r|r|r}
\hline \multicolumn{1}{c}{} & \multicolumn{2}{c}{$\begin{array}{c}\text { Sum of } \\
\text { Squares }\end{array}$} & \multicolumn{1}{c}{ df } & \multicolumn{1}{c}{ Mean Square } & \multicolumn{1}{c}{ Sig. } \\
\hline 1 & Megression & 18,691 & 5 & 3,738 & 27,265 &, $000^{\mathrm{b}}$ \\
& Residual & 8,501 & 62 &, 137 & & \\
& Total & 27,192 & 67 & & & \\
\hline
\end{tabular}

a. Dependent Variable: Performance

b. Predictors: (Constant), Fairness, Transparancy, Accountability, Responsibility, Independency 
Tabel 6.

\section{Coefficients $^{\mathrm{a}}$}

\begin{tabular}{|c|c|c|c|c|c|c|}
\hline \multirow{2}{*}{ Model } & \multirow[b]{2}{*}{ B } & \multicolumn{2}{|c|}{$\begin{array}{c}\text { Unstandardized } \\
\text { Coefficients }\end{array}$} & \multirow[t]{2}{*}{$\begin{array}{c}\text { Standardized } \\
\text { Coefficients }\end{array}$} & \multirow[b]{2}{*}{$\mathbf{t}$} & \multirow[b]{2}{*}{ Sig. } \\
\hline & & Std. Error & Beta & & & \\
\hline \multirow[t]{6}{*}{1} & (Constant) & ,862 & ,343 & & 2,513 & ,015 \\
\hline & Transparancy & 204 &, 083 & ,206 & 2,446 &, 017 \\
\hline & Accountability & , 112 & ,087 &, 132 & 1,286 & ,203 \\
\hline & Responsibility & ,222 & ,085 & ,249 & 2,605 &, 011 \\
\hline & Independency &,- 067 & ,115 &,- 061 &,- 582 & ,562 \\
\hline & Fairness & ,336 & ,065 & ,510 & 5,193 & ,000 \\
\hline
\end{tabular}

a. Dependent Variable: Performance 